\title{
PAIKKA JA VÄLITILA
}

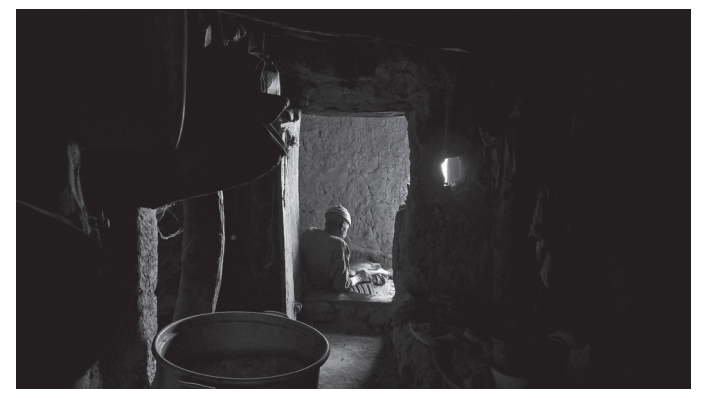

JOUNI KAIPIA: OVIMIES. IRELI, MALI. 2012.

Arkkitehti Jouni Kaipian (s. 1956) kiinnostus on sitten 1990-luvun lopun vähitellen siirtynyt aikalaisrakentamisen kysymyksistä arkkitehtuurin arkkityyppisten lähtökohtien tarkasteluun. Asuminen, asumus, asunto, taloksi asettuminen, koti ja paikka ovat hänen tutkimuskohteitaan. Kaipia on maailmanmatkaaja ja ahkera valokuvaaja, erityisesti Aasia ja Afrikka ovat vanginneet hänen huomionsa. Näistä maanosista voi hänestä vielälöytää sellaisia ikiaikaisia asumisen muotoja, jotka ovat länsimaista kadonneet. Kaipiasta vasta asukkaat tekevät arkkitehtuurin

Nuori nainen istuu Mpigissä Ugandassa kotitalonsa jykevällä kynnyksellä selusta vielä turvattuna uteliaana ottamassa askeleita uuteen. Hän on välitilassa. Oviaukon verho on näkösuoja kodin yksityisyyteen. Ovensuun edessä istuva dogon-mies Irelissä Malissa on antanut kuvaajan tulla sisään perinteisen talonsa keittiöön asti. Talo on sukupuolittunut; keittiö on naisten valtakuntaa, ja varsinainen julkinen tila on miehinen. Ajatuksiinsa syventynyt mies on eteisen kaltaisessa välitilassa.

Perinne ja nykyaika leikkaavat moskeijassa Istanbulissa. Huivilla päänsä peittänyt lattialla istuva nainen lähettää rukouksen lomassa tekstiviestiä. Käsipuhelimen lisäksi virtaviivaiset muovijakkarat ovat uusi tulokas moskeijan ornamentein koristellussa tilassa. Munkki Drepungin luostarissa Tibetissä istuu patjallaan rauhallisena ja hyväntahtoisena niin kuin olisi aina istunut. Hän on kiireettömästi osa henkisen kilvoittelun yhteisöään. Hänellä on myös aikaa katsoa kuvaajaan hyväksyvästi.

Pari poikaa, koululaisia, Utön satamalaiturilla on odottamassa yhteyslauttaa mantereelle. Punainen alus on kiinnittymässä laituriin. On noustu varhain ja nyt matkataan viikoksi koulunpenkille mantereelle.Togon Agbannakissa pojat istuvat Place Republiquen laidalla omissa ajatuksissaan, hekin välitilassa. Jotain mielenkiintoista on aukiolla tapahtunut tai kohta tapahtumassa. Jokainen on yksilö, avoimempi tai varautuneempi. Vaatetus on osin perinteistä, osin yleismaailmallista länsimaista nuorisotyyliä.

Naiset osallistuvat Beninin Grand Popossa meren jumalan Mami Watan juhlintaan. He tietävät paikkansa ja arvonsa, jota perinteinen pukeutuminen korostaa. Kuvaaja on taustalla, eikä tohdi tällä kertaa häiritä tilannetta. Kolme naista Paganissa Burmassa viettävät joutohetkeä istumalla, kykkimällä katukäytävällä. Sikari vie keskimmäisen huomion, mutta oikeapuolinen on jo pitkästynyt odottamaan kuvaushetkeä. Naisten läsnäolo on kuitenkin vahvaa ja elämänmakuista.

Le Corbusierin moderni, rosoisen konstruktiivinen arkkitehtuuri ja intialainen elämänmuoto ovat eri maailmoja. Ahmedebadissa sijaitsevan betonisen yhdistysrakennuksen asiointitila keltaiseksi maalattuine seinineen vaihtuu palvelutason toisella puolella vahtimestarin byrokraattiseen hämärään. Jännitteistään huolimatta Kaipian mielestä Le Corbusierin rakennusten arkaisuus ja perinteinen Intia keskustelevat keskenään luontevasti. 